\title{
Fire effects on tobosagrass and weeping lovegrass
}

FRED H. ROBERTS, CARLTON M. BRITTON, DA VID B. WESTER, AND ROBERT G. CLARK

Abstract

Fireline intensity $(\mathrm{kW} / \mathrm{m})$ was measured on 61 plots of weeping lovegrass [Eragrostis curvula (Schrad.) Nees.] and tobosagrass [Hilaria mutica (Buckl.) Benth.] burned as headfires and backffres during late winters of 1982 and 1983 in weatem Texas. Relative humidity, air temperature, wind speed, soil moisture, soil temperature, and fuel moisture were measured at time of burning. Vegetation response was based on plant yield, plant height, and number of seed stalks. Plant responses were not correlated with fireline intensity or any of the environmental parameters measured. Although fireline intensity is an important fire behavior measurement, high freline intensities did not cause a negative impact on either weeping lovegrass or tobosagrass. Therefore, range managers can conduct high intensity fires to damage or burn down shrubs and not damage these grasses.

Key Words: prescribed fire, fireline intensity, yield, busal area, plant height, seed stalks, Hilaria mutica, Eragrostis curvula

Fire intensity is a commonly used term in prescribed fire literature. Virtually every vegetative response associated with prescribed fire or wildfire has been attributed to fire intensity (Wright and Bailey 1982). The hypothesis that a hot, intense, fast-moving fire results in more damage to grasses compared to a less intense, slow-moving fire has not been adequately tested in grassland communities.

Byram (1959) defined fireline intensity as heat released per unit time per unit length of fire front. Numerically, fireline intensity $(\mathrm{kW} / \mathrm{m})$ is the product of available fuel $\left(\mathrm{kg} / \mathrm{m}^{2}\right)$, heat yield of the fuel $(\mathrm{kJ} / \mathrm{kg})$, and the forward rate of spread of the fire front $(\mathrm{m} / \mathrm{s})$. Therefore, fireline intensity integrates several important characteristics and is useful in predicting fire behavior.

Previous conclusions about the effect of fire intensity on herbaceous vegetation in grasslands have been based on artificial ratings of fire intensity. Blaisdell (1953) and Conrad and Poulton (1966) rated fire intensity based on the quantity of stems remaining or to the general level of fine fuel consumption after burning. These observed fire intensities were positively correlated to plant damage. However, Wright and Klemmedson (1965) observed that certain leafy bunchgrasses died following fire regardless of apparent intensity of the passing fire. The objective of this study was to measure a range of fireline intensities and determine the subsequent effect on yield, plant height, and number of seed stalks for 2 grasses in west Texas.

\section{Materials and Methods}

Weeping lovegrass [Eragrostis curvula (Schrad.) Nees.] plots burned in 1982 and 1983 were $5 \mathrm{~km}$ north of Brownfield, Texas, at $1,000 \mathrm{~m}$ elevation. Climate of the area is warm, temperate, subhumid, continental with mean annual precipitation of $47 \mathrm{~cm}$. Soil is an Amarillo loamy fine sand (Aridic Paleustalf) with caliche at 1.2 to $1.8 \mathrm{~m}$ (Miller et al. 1959). Study plots were located in a relatively homogeneous, ungrazed, decadent stand established in 1976.

Tobosagrass [Hilaria mutica (Buckl.) Benth.] plots were $11 \mathrm{~km}$

\footnotetext{
Authors were research assistant, associate professor, research scientist, and research assistant, Department of Range and Wildlife Management, Texas Tech University, Lubbock 79409. This study was supported in part by a grant from the Intermountain Fire Sciences Laboratory, USDA Forest Service. This is a contribution of the College of Agricultural Sciences, Texas Tech University, No. T-9-438.

Manuscript accepted 13 April 1988.
}

southeast of Gail, Texas, at $800 \mathrm{~m}$ elevation and were protected from grazing throughout the study by an electric fence. Average annual precipitation is $44 \mathrm{~cm}$ and the soil is classified as a Stamford clay (Typic Chromustert) (Dixon 1975).

Sixty-one plots were burned from 2 February to 15 April 1982 and from 14 March to 28 April 1983. Seventeen plots were burned as headfires and 10 plots as backfires in weeping lovegrass. Twenty-two plots were burned as headfires and 12 as backfires in tobosagrass. The minimum plot size was 20 by $20 \mathrm{~m}$. Fires were ignited under a variety of weather conditions to produce a wide range of fireline intensities (Clark 1983).

Standing crops of fine fuel were estimated by clipping ten, $0.25-\mathrm{m}^{2}$ quadrats in weeping lovegrass and fifteen, $0.0625-\mathrm{m}^{2}$ quadrats in tobosagrass adjacent to the fire run in each plot. Samples were oven dried at $60^{\circ} \mathrm{C}$ to a constant weight, then weighed to the nearest $0.1 \mathrm{~g}$. Heat yield of fine fuel was determined from duplicate subsamples in an oxygen bomb calorimeter. A final reduction correction of $23.9 \mathrm{~kJ} / \mathrm{kg} / \% \mathrm{MC}$ (MC = weighted moisture content) was made to account for the difference between heat content determined in the laboratory with oven-dry samples and the additional moisture contained in each fuel component during test fires (Van Wagner 1973). Rate of fire spread was determined by photographing the spreading fire with infrared film using metal stakes to mark distances (Britton et al. 1977). Byram's fireline intensity was calculated as the product of fine fuel, heat yield, and rate of fire spread.

Soil samples were taken from the surface $5 \mathrm{~cm}$ at 5 random locations per plot and placed in airtight cans prior to each burn. The samples were weighed, then dried at $105^{\circ} \mathrm{C}$ for $48 \mathrm{hr}$ and reweighed. Soil water contents were determined gravimetrically. Soil and grass crown temperatures were measured with soil thermometers $1 \mathrm{~cm}$ below grass crowns in 5 randomly located plants prior to burning. Readings were taken after a 10-minute equilibration period. Fuel moisture samples were taken prior to each burn and weighed in the field. Samples were then oven dried at $60^{\circ} \mathrm{C}$ for $48 \mathrm{hr}$ and reweighed. Fuel moisture was expressed as a percent of the dry weight. Air temperature and relative humidity were determined within 3 min of ignition with a sling psychrometer (Anon. 1959). Wind speed at $\mathbf{2} \mathrm{m}$ was measured with a totalizing anemometer (Clark et al. 1981).

Grass responses were estimated after 1 growing season. Fifteen $0.0625-\mathrm{m}^{2}$ quadrats were randomly located in each tobosagrass plot. The height of the tallest leaf was measured and number of seedstalks was counted in each quadrat. Vegetation was then clipped $1 \mathrm{~cm}$ above the soil surface. Ten, $0.25-\mathrm{m}^{2}$ quadrats were similarly located and sampled in the weeping lovegrass plots. Samples were dried at $60^{\circ} \mathrm{C}$ until weight was constant then weighed to the nearest $0.1 \mathrm{~g}$.

Percentage change in basal area was measured on weeping lovegrass plots that were burned in 1982 . Ten quadrat locations were permanently marked in each plot. Initial basal area was measured after each burn to minimize fuel continuity disturbance. Residual crown stubble was sufficient to obtain preburn basal area. Blackand-white, overhead photographs were made of each quadrat. Photographs were retaken after clipping at the end of the growing season. Five randomly placed lines were drawn through each print and basal area was measured by line intercept method. Percentage change in basal area was calculated from the difference in the initial and final measurements. Basal area measurements were not made 
Table 1. Fireline intensity and plant responses to spring burns of tobosagrass conducted in west Texas.1

\begin{tabular}{|c|c|c|c|c|c|c|c|}
\hline \multirow[t]{2}{*}{$\begin{array}{l}\text { Burn } \\
\text { date }\end{array}$} & \multicolumn{2}{|c|}{$\begin{array}{c}\text { Yield } \\
\text { (kg/ha) }\end{array}$} & $\begin{array}{l}\text { Intensity } \\
(\mathrm{kW} / \mathrm{m})\end{array}$ & \multicolumn{2}{|c|}{$\begin{array}{c}\text { Seedstalk } \\
\text { number } \\
\left(\mathrm{No} / \mathrm{m}^{2}\right)\end{array}$} & \multicolumn{2}{|c|}{$\begin{array}{c}\text { Height } \\
\text { (cm) }\end{array}$} \\
\hline & \multicolumn{7}{|c|}{ Headfires } \\
\hline $\begin{array}{l}3 / 13 / 82 \\
3 / 13 \\
3 / 19 \\
3 / 19 \\
3 / 19 \\
3 / 19 \\
3 / 20 \\
3 / 20 \\
3 / 20 \\
3 / 27 \\
3 / 27 \\
3 / 27 \\
3 / 27 \\
3 / 15 / 83 \\
3 / 15 \\
3 / 15 \\
3 / 18 \\
3 / 18 \\
3 / 18 \\
3 / 31 \\
3 / 31 \\
4 / 19\end{array}$ & $\begin{array}{r}2089 \\
2360 \\
3888 \\
2176 \\
2418 \\
3156 \\
2386 \\
2185 \\
3735 \\
2737 \\
2850 \\
3127 \\
1821 \\
1406 \\
1563 \\
2037 \\
1399 \\
2273 \\
1298 \\
1413 \\
1296 \\
549\end{array}$ & $\begin{array}{r}(227) \\
(194) \\
(267) \\
(245) \\
(211) \\
(314) \\
(163) \\
(248) \\
(480) \\
(194) \\
(255) \\
(281) \\
(84) \\
(145) \\
(116) \\
(337) \\
(145) \\
(242) \\
(127) \\
(175) \\
(151) \\
(53)\end{array}$ & $\begin{array}{r}2699 \\
5223 \\
4752 \\
1649 \\
2908 \\
3576 \\
85 \\
1083 \\
1424 \\
392 \\
591 \\
1273 \\
992 \\
1597 \\
302 \\
558 \\
646 \\
438 \\
170 \\
4453 \\
8036 \\
1893\end{array}$ & $\begin{array}{r}40 \\
84 \\
44 \\
24 \\
40 \\
84 \\
24 \\
32 \\
52 \\
76 \\
84 \\
92 \\
92 \\
12 \\
32 \\
40 \\
40 \\
48 \\
52 \\
40 \\
40 \\
4\end{array}$ & $\begin{array}{r}(7) \\
(8) \\
(5) \\
(3) \\
(5) \\
(10) \\
(4) \\
(4) \\
(13) \\
(6) \\
(8) \\
(12) \\
(9) \\
(4) \\
(5) \\
(13) \\
(8) \\
(7) \\
(9) \\
(10) \\
(7) \\
(2)\end{array}$ & $\begin{array}{l}39 \\
40 \\
47 \\
36 \\
36 \\
34 \\
40 \\
38 \\
43 \\
42 \\
43 \\
41 \\
40 \\
16 \\
22 \\
18 \\
19 \\
22 \\
21 \\
20 \\
21 \\
17\end{array}$ & $\begin{array}{l}\text { (2) } \\
\text { (1) } \\
(2) \\
(2) \\
(2) \\
(2) \\
(1) \\
(2) \\
(2) \\
(2) \\
(2) \\
(2) \\
(1) \\
(1) \\
(2) \\
(2) \\
(1) \\
(1) \\
(1) \\
(1) \\
(1) \\
(1)\end{array}$ \\
\hline $4 / 19$ & \multicolumn{7}{|c|}{ Backfires } \\
\hline $\begin{array}{l}3 / 13 / 82 \\
3 / 13 \\
3 / 19 \\
3 / 19 \\
3 / 19 \\
3 / 20 \\
3 / 27 \\
3 / 15 / 83 \\
3 / 15 \\
3 / 18 \\
3 / 31 \\
4 / 19\end{array}$ & $\begin{array}{r}2997 \\
2971 \\
2591 \\
2291 \\
3223 \\
3199 \\
2601 \\
1111 \\
1033 \\
595 \\
1673 \\
756\end{array}$ & $\begin{array}{r}(234) \\
(349) \\
(166) \\
(141) \\
(354) \\
(226) \\
(169) \\
(165) \\
(92) \\
(98) \\
(199) \\
(92)\end{array}$ & $\begin{array}{r}108 \\
101 \\
61 \\
103 \\
130 \\
51 \\
41 \\
63 \\
60 \\
53 \\
125 \\
97\end{array}$ & $\begin{array}{r}36 \\
56 \\
16 \\
64 \\
68 \\
44 \\
53 \\
20 \\
8 \\
28 \\
40 \\
0\end{array}$ & $\begin{array}{l}(6) \\
(8) \\
(3) \\
(5) \\
(9) \\
(6) \\
(5) \\
(9) \\
(3) \\
(7) \\
(9) \\
(0)\end{array}$ & $\begin{array}{l}42 \\
44 \\
40 \\
31 \\
38 \\
37 \\
45 \\
37 \\
15 \\
23 \\
21 \\
17\end{array}$ & $\begin{array}{l}\text { (2) } \\
\text { (1) } \\
\text { (1) } \\
(2) \\
(2) \\
(1) \\
(2) \\
(2) \\
(1) \\
(3) \\
(1) \\
\text { (1) }\end{array}$ \\
\hline
\end{tabular}

IStandard errors are included in parentheses.
Table 2. Fireline intensity and plant responses to spring burns of weeping lovegrass conducted in weat Texas.'

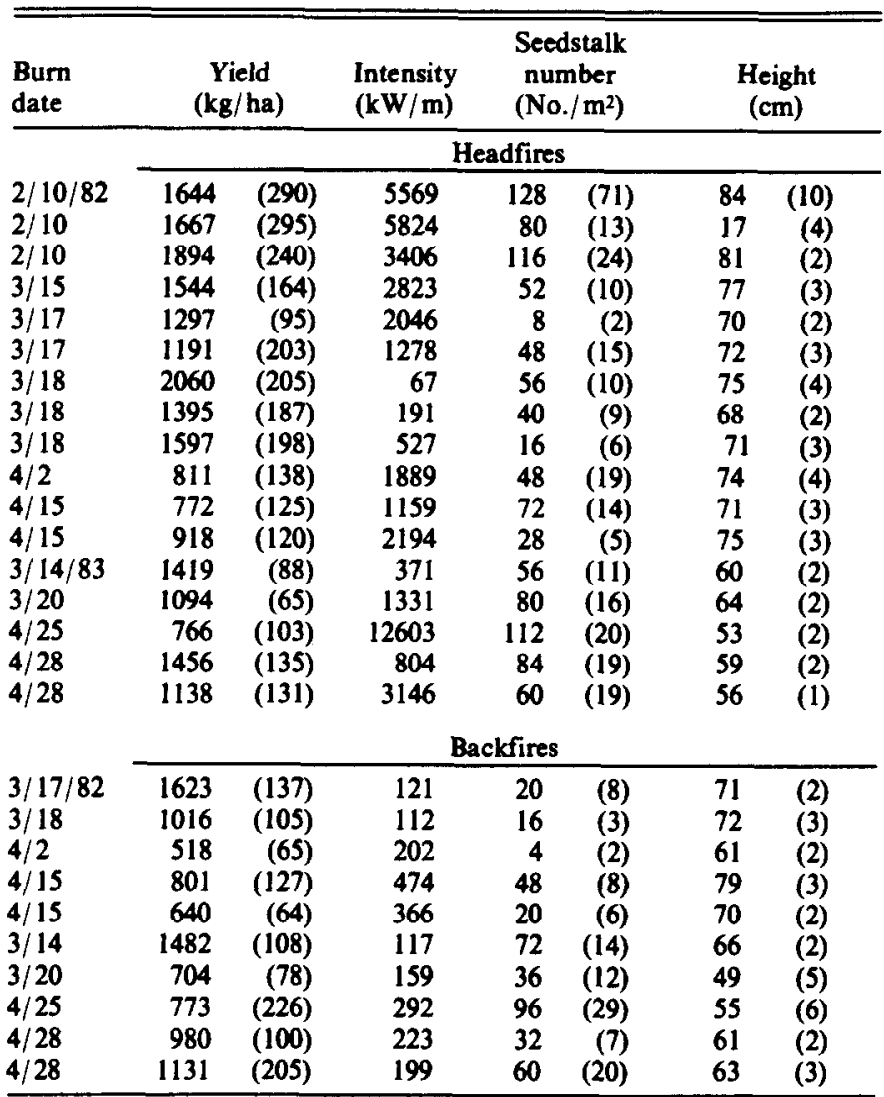

istandard errors are shown in parentheses.

Table 3. Basic statistics of headfires and backfires in tobosagrass and weeping lovegrass for burns conducted in west Texas in 1982 and 1983.

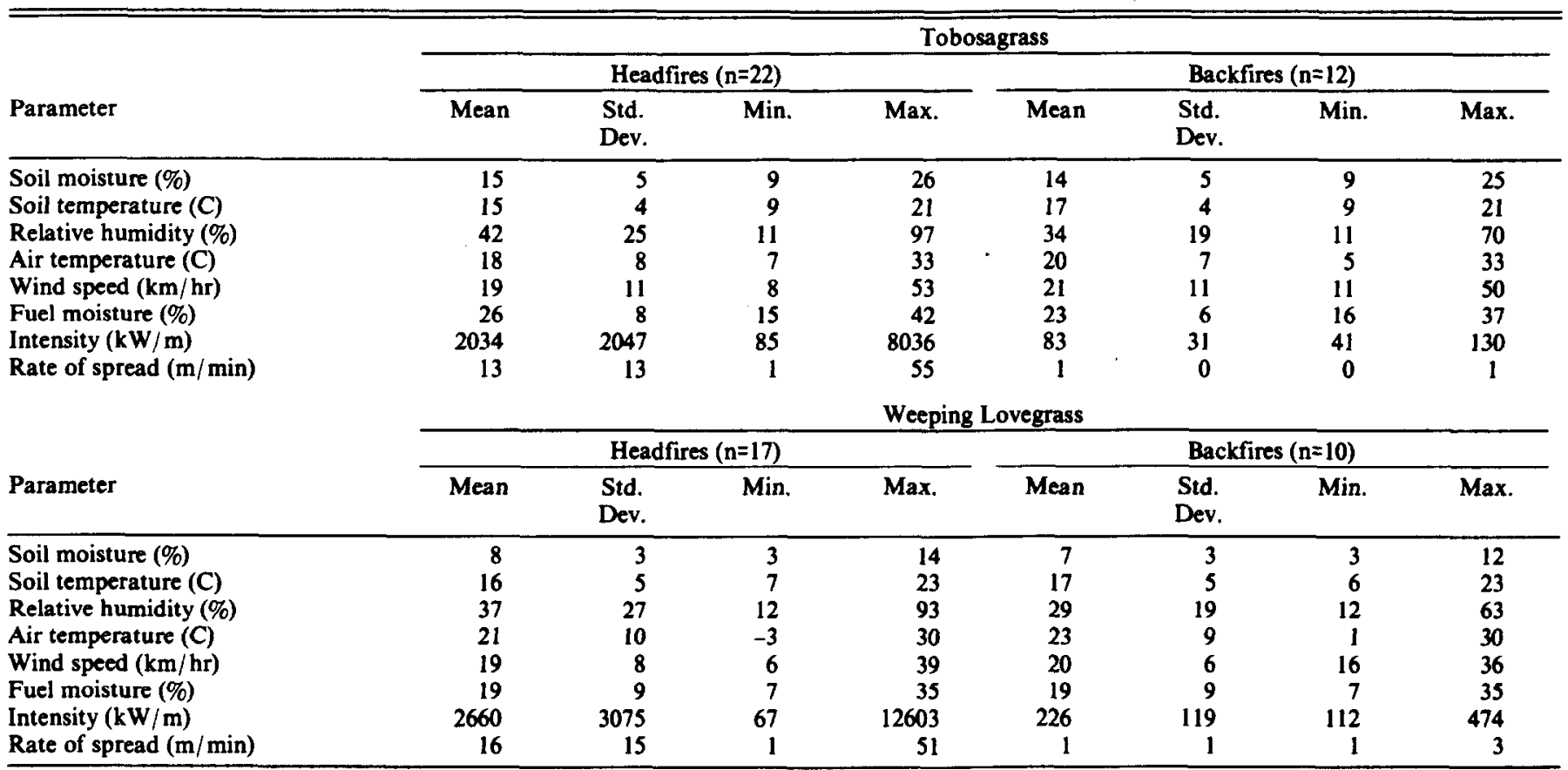


on tobosagrass due to its rhizomatous growth form.

Correlation analysis was used to determine if significant relationships existed between plant response and fireline intensity or environmental variables. Since burns were conducted in 2 years and at several different dates each year on plots with varying initial fuel loads, multiple regression was used to account for effects of years, dates, and initial yield in models relating plant response to fireline intensity and environmental variables. The importance of fireline intensity and environmental variables in these models was evaluated with partial correlation coefficients.

\section{Results and Discussion}

Data on fire intensities and grass yields, seedstalk numbers, and plant heights of tobosagrass and weeping lovegrass one season after burning are presented in Tables 1 and 2 . Although over both years fireline intensities varied from 85 to $8,036 \mathrm{~kW} / \mathrm{m}$ for tobosagrass headfires and from 67 to $12,603 \mathrm{~kW} / \mathrm{m}$ for weeping lovegrass headfires (Table 3), no significant correlation was found between fireline intensity and yield of either grass (Table 4). The range of

Table 4. Correlation of plant response variables to various independent variables for headfires conducted in tobosagrass (TG) and weeping lovegrass (WLG) during 1982 to 1983 in West Texas.

\begin{tabular}{|c|c|c|c|c|c|c|}
\hline \multirow[b]{3}{*}{ Independent variables } & \multicolumn{6}{|c|}{ Dependent variables } \\
\hline & \multicolumn{2}{|c|}{$\begin{array}{c}\text { Yield } \\
\text { (kg/ha) }\end{array}$} & \multicolumn{2}{|c|}{$\begin{array}{l}\text { Plant height } \\
\text { (cm) }\end{array}$} & \multicolumn{2}{|c|}{$\begin{array}{c}\text { Seed stalks } \\
\left(\text { No. } / \mathbf{m}^{2}\right)\end{array}$} \\
\hline & TG & WLG & TG & WLG & TG & WLG \\
\hline Fireline intensity $(\mathrm{kW} / \mathrm{m})$ & 0.00 & 0.00 & 0.00 & 0.00 & 0.01 & 0.14 \\
\hline Relative humidity (\%) & 0.05 & 0.09 & 0.00 & 0.00 & 0.12 & 0.02 \\
\hline Air temperature $\left({ }^{\circ} \mathrm{C}\right)$ & 0.02 & -0.07 & 0.00 & -0.03 & -0.01 & -0.06 \\
\hline Wind speed (km/hr) & 0.00 & -0.01 & 0.00 & 0.00 & 0.00 & 0.00 \\
\hline Soil moisture (\%) & 0.01 & 0.00 & 0.00 & 0.03 & 0.05 & 0.00 \\
\hline Soil temperature $\left({ }^{\circ} \mathrm{C}\right)$ & -0.05 & -0.06 & -0.01 & -0.02 & 0.02 & -0.10 \\
\hline Fuel moisture (\%) & 0.04 & 0.09 & 0.00 & 0.00 & 0.12 & 0.03 \\
\hline
\end{tabular}

fireline intensity was smaller for backfires for grasses (Table 3) and no significant correlations were detected (Table 5). None of the measured independent variables were significantly correlated with yield, plant heights, or seedstalk number of either grass for the 2 fire types.

Table 5. Correlation of plant response variables to various independent variables for backfires conducted in tobosagrass (TG) and weeping lovegrass (WLG) during 1982 to 1983 in Weat Texas.

\begin{tabular}{|c|c|c|c|c|c|c|}
\hline \multirow[b]{3}{*}{ Independent variables } & \multicolumn{6}{|c|}{ Dependent variables } \\
\hline & \multicolumn{2}{|c|}{$\begin{array}{c}\text { Yield } \\
(\mathrm{kg} / \mathrm{ha})\end{array}$} & \multicolumn{2}{|c|}{$\begin{array}{l}\text { Plant height } \\
\text { (cm) }\end{array}$} & \multicolumn{2}{|c|}{$\begin{array}{c}\text { Seed stalks } \\
\left(\mathrm{No} / \mathrm{m}^{2}\right)\end{array}$} \\
\hline & TG & WLG & TG & WLG & TG & WLG \\
\hline Fireline intensity $(\mathrm{kW} / \mathrm{m})$ & 0.01 & 0.00 & 0.00 & 0.12 & 0.11 & 0.10 \\
\hline Relative humidity (\%) & 0.01 & -0.48 & 0.02 & -0.04 & 0.00 & -0.03 \\
\hline Air temperature $\left({ }^{\circ} \mathrm{C}\right)$ & 0.01 & 0.41 & 0.00 & 0.08 & 0.03 & 0.28 \\
\hline Wind speed $(\mathrm{km} / \mathrm{hr})$ & 0.00 & -0.04 & 0.00 & -0.08 & -0.01 & -0.18 \\
\hline Soil moisture (\%) & 0.00 & 0.08 & 0.02 & -0.03 & 0.11 & 0.00 \\
\hline Soil temperature $\left({ }^{\circ} \mathrm{C}\right)$ & 0.01 & 0.28 & 0.00 & 0.13 & 0.01 & 0.23 \\
\hline Fuel moisture (\%) & 0.00 & -0.37 & 0.00 & -0.02 & -0.01 & -0.02 \\
\hline
\end{tabular}

Percentage change in basal area of weeping lovegrass varied from $+3.5 \%$ to $-5.3 \%$ on headfired plots, compared to a range from $+3.7 \%$ to $-1.2 \%$ on backfired plots. Change in basal area of weeping lovegrass was not correlated with fireline intensity $(r=0.45$; N.S.)

Fireline intensity is useful in forest communities for predicting maximum height of lethal scorch of conifer needles (Van Wagner 1973) and describing the general nature of wildfire for aid in suppression activities (Albini 1976). Although rarely used in rangeland situations, fireline intensity is equally important for predicting scorch height of shrubs. Rate-of-spread is the primary factor influencing intensity for a given fuel type, therefore, wind speed is an important parameter. Wind speed was the dominant factor influencing burndown of mesquite stems (Britton and Wright 1971) and consumption of mesquite debris on the soil surface in mesquite-tobosagrass communities (McPherson and Wright 1986). Although wind speed is easily measured and an important parameter, fireline intensity should have more biological sensitivity since it reflects the heat yield per unit time per unit length of fire front and integrates the effects of wind speed, temperature, humidity, fuel moisture, and fuel characteristics through rate-of-speed.

Tobosagrass and weeping lovegrass yields were not adversely affected by high levels of fireline intensity. Griffin and Friedel (1984) measured fireline intensity on 7 burns in central Australia. Fireline intensity varied from 35 to $1,902 \mathrm{~kW} / \mathrm{m}$, but fireline intensity did not affect herbaceous vegetation (primarily the genera Aristida, Enneapogon, and Digitaria). Fireline intensity had no effect on the herbaceous layer under a ponderosa pine overstory (Armour et al. 1984). The limited literature available on fireline intensity supports our results that intensity does not strongly affect herbaceous vegetation. This is important because a fast-moving fire with long flame lengths will not damage herbaceous vegetation any more than a slow moving fire with short flame lengths. Thus, a prescribed burn can be conducted under ambient conditions favorable for burning down woody stems, consuming debris, and scorching the aerial portions of shrubs. Concerns about damaging grasses with high intensity fires were not validated in this study. Therefore, managers can apply intense fires to meet a variety of objectives without fear of reduced grass yields or vigor.

\section{Literature Cited}

Albini, F.A. 1976. Estimating wildfire behavior and effects. USDA Forest Serv. Res. Note INT-30. Intermountain Forest and Range Exp. Sta., Ogden, Utah.

Anonymous. 1959. Belt weather kit. Fire Control Notes. 20:122-123.

Armour, C.D., S.C. Bunting, and L.F. Neuenschwander. 1984. Fire intensity effects on the understory in ponderosa pine forests. J. Range Manage. 37:44-49.

Bhaisdell, J.P. 1953. Ecological effects of planned burning of sagebrushgrass range on the upper Snake River Plains. USDA Tech. Bull. 1075. Washington, D.C.

Britton, C.M., and H.A. Wright. 1971. Correlation of weather and fuel variables to mesquite damage by fire. J. Range Manage. 24:136-141.

Britton, C.M., B.L. Karr, and F.A. Sneva. 1977. A technique for measuring rate of fire spread. J. Range Manage. 30:395-397.

Byram, G.M. 1959. Combustion of forest fuels, p. 61-89. In: K.P. Davis (ed.) Forest fire: control and use. McGraw-Hill Book Co., New York.

Clark, R.G., A.A. Steuter, and C.M. Britton. 1981. An inexpensive anemometer frame. Fire Manage. Notes 42:13-14.

Clark, R.G. 1983. Threshold requirements for fire spread in grassland fuels. Ph.D. Diss. Texas Tech Univ. Lubbock.

Conrad, C.E., and C.E. Poulton. 1966. Effect of a wildfire on Idaho fescue and bluebunch wheatgrass. J. Range Manage. 19:138-141.

Dixon, M.L. 1975. Soil survey of Borden County, Texas. USDA Soil Conserv. Serv., U.S. Gov. Printing Off., Washington, D.C.

Griffin, G.F., and M.H. Friedel. 1984. Effects of fire on central Australian rangelands. I. Fire and fuel characteristics and changes in herbage and nutrients. Aust. J. Ecol. 9:381-393.

MePherson, G.R., and H.A. Wright. 1986. Threshold requirements for burning downed honey mesquite. J. Range Manage. 39:327-330.

Miller, W.M., D. Sanders, J.J. Whitmore, P.M. Boden, J.D. McAndrews, and H.W. Hyde. 1959. Soil survey of Terry County, Texas. USDA Soil Conserv. Serv., U.S. Gov. Print. Off., Washington, D.C.

Van Wagner, C.E. 1973. Height of crown scorch in forest fires. Can. J. Forest. Res. 3:373-378.

Wright, H.A., and A.W. Balley. 1982. Fire ecology: United States and Southern Canada. John Wiley and Sons, New York.

Wright, H.A., and J.O. Klemmedson. 1965. Effects of fire on bunchgrasses of the sagebrush-grass region in southern Idaho. Ecology 46:680-688. 